Sporting Blackness 



\section{Sporting Blackness}

Race, Embodiment, and Critical Muscle Memory on Screen

SAMANTHA N. SHEPPARD

ㄸ

University of California Press 
University of California Press

Oakland, California

(C) 2020 by Samantha N. Sheppard

Library of Congress Cataloging-in-Publication Data

Names: Sheppard, Samantha N., author.

Title: Sporting blackness : race, embodiment, and critical muscle memory on screen / Samantha N. Sheppard.

Description: Oakland, California : University of California Press, [2020] | Includes bibliographical references and index.

Identifiers: LCCN 2019059432 (print) | LCCN 2019059433 (ebook) | ISBN 9780520307773 (cloth) | ISBN 9780520307797 (paperback) | ISBN 9780520973855 (ebook)

Subjects: LCSH: Sports in motion pictures. | African Americans in motion pictures. | Race in motion pictures.

Classification: LCC PN1995.9.s67 S54 2020 (print) | LCC PN1995.9.s67 (ebook) | DDC 791.43/6579-dc23

LC record available at https://lccn.loc.gov/2019059432

LC ebook record available at https://lccn.loc.gov/2019059433

Manufactured in the United States of America

$\begin{array}{llllllllll}29 & 28 & 27 & 26 & 25 & 24 & 23 & 22 & 21 & 20\end{array}$

$\begin{array}{llllllllll}10 & 9 & 8 & 7 & 6 & 5 & 4 & 3 & 2 & 1\end{array}$ 
For the home team:

Allen, Bayard, and Baldwin 
